\title{
Konsep Dan Bentuk Ruang Rakkeang Rumah Tradisional Bangsawan Bugis di Bone Sulawesi Selatan
}

\author{
${ }^{1}$ Andi Muhammad Akbar \\ Program Studi Arsitektur, Fakultas Teknik, Universitas Muslim Indonesia
}

\section{Intisari}

Arsitektur tradisional Bugis erat kaitannya dengan sejarah kerajaan Bugis pada masa lalu, dimana Kota Bone sebagai basisnya di Sulawesi Selatan. Didalam rumah tradisional bangsawan Bugis Bone terbagi atas 3 ruang secara vertikal yaitu: Rakkeang, Alle Bola dan Awa Bola. Konsep bentuk ruang yang khas pada Rakkeang mampu memberikan ekspresi karakteristik tersendiri, sehingga perlu diteliti lebih mendalam sebagai aset karya arsitektur nasional penghubung masa yang lalu dan masa yang akan datang. Tujuan penelitian ini menemukan konsep bentuk ruang Rakkeang yang berpengaruh terhadap karakter arsitektur rumah tradisional bangsawan Bugis. Penelitian ini mencakup basis kerajaan suku Bugis di Kabupaten Bone. Metedologi penelitian ini kualitatif dengan pendekatan paradigma rasionalistik. Hasil penelitian bentuk ruang Rakkeang ini secara spasial terletak simetris dengan Indo Bola dan cenderung mengikuti pola ruang yang ada dibawahnya, semakin besar ukuran ruang Rakkeang semakin tinggi derajat kebangsawanannya, Sedangkan orientasi ruang Rakkeang menghadap kejalan dan hirarki ruang merupakan simbol kewibawaan dengan fungsi khusus yang sifatnya privasi. Secara fisik konsep bentuk Rakkeang simetris berukuran lebih besar dan kemampuan variasi konstruksinya lebih varatif. Hal ini sebagai simbol derajat sosial dan kemampuan penghuni secara ekonomis. Sedangkan bentuk elemen-elemen Rakkeang dimaksudkan agar hegemoni kebangsawanan tetap diterjaga, dan dapat mempengaruhi persepsi setinggi apa status sosialnya dalam masyarakat.

\section{Kata Kunci: Konsep Bentuk Rakkeang Bangsawan Bone}

\section{PENDAHULUAN}

Arsitektur tradisional di Indonesia memiliki bentuk yang sangat khas dan bervariasi, namun sejumlah ciri-ciri khusus masih kurang terlihat. Ciri-ciri umum yang sering kita lihat merupakan warisan budaya dari leluhur austronesian, yaitu bentuk atap dan tiang-tiang yang tinggi pada bangunan rumah tradisionalnya. Arsitektur tradisional suku Bugis juga memiliki unsur kebudayaan nasional yang mempunyai bentuk fisik, fungsi dan style serta proses pembuatannya senantiasa memberikan karakter tersendiri. Suku Bugis memandang rumahnya tidak hanya sekedar tempat tinggal tetapi juga sebagai ruang pusat siklus kehidupan yaitu: tempat manusia dilahirkan, dibesarkan, menikah dan meninggal, oleh karena itu membangun rumah haruslah didasarkan tradisi dan kepercayaan yang diwarisi secara turun temurun dari leluhur. ${ }^{(1)}$

Arsitektur tradisional suku Bugis di Sulawesi Selatan sangat erat kaitannya dengan sejarah kerajaan Bugis pada masa lalu, dimana Kota Bone dahulu sebagai pusat kerajaan suku Bugis di Sulawesi Selatan sehingga bangunan yang dibuat umumnya menghadap ke arah laut seperti halnya istana Soraja Petta Ponggawa'E di kota Bone. Wujud fisik rumah tradisional masyarakat Bugis sangat dipengaruhi stratafikasi sosial yang berlaku dimasyarakatnya, pemahaman ini berdasar Lontara Sure La Galigo, dimana Tomanurung mengajarkan paham ketatanegaraan turun dari langit sebagai Dewata Seuwae untuk memerintah bumi, dimana kekuasaan diturunkan oleh Dewata' kepada manusia melalui raja sebagai wakil dewa di dunia. Didalam rumah tradisional suku Bugis, alam semesta ini sebagai pandangan hidupnya yang terdiri atas 3 bagian dilihat secara vertikal, dimana dunia atas digambarkan sebagai tempat penyembah terhadap Dewa Langi' yang diadakan di rakkeang sebutan umum sebagai tempat yang tertinggi dari struktur rumah atau biasa juga disebut loteng atau tollangeng, sedangkan dunia tengah dari struktur ruang rumah suku Bugis yaitu tempat penyembahan Dewa Malino yang dianggap berdiam di Ale Bola atau badan rumah dan dunia bawah dari struktur ruang rumah Bugis yaitu tempat penyembahan Dewa UwaE yang dianggap bersemanyam di Awa Bola atau kolong rumah ${ }^{(2)}$

Dunia atas pada rumah tradisional bangsawan Bugis biasa dan sering juga disebut Rakkeang dalam bahasa Bugis, yaitu ruang yang berada dibawah atap. Analogi yang sering kita dengar dari berbagai pendapat atau cerita dari masyarakat Bugis bahwa Dunia Atas atau Botting langi merupakan penjelmaan kehidupan diatas alam sadar manusia yang terkait dengan kepercayaan yang tidak tampak yaitu: disakralkan, dikeramatkan, disucikan, dan kebaikan lainnya, atau sugestilainnya. Pemahaman ini mereka mengibaratkan sebagai sesuatu yang ditinggikan atau Arrajange dalam bahasa Bugisnya, sedangkan pemahaman masyarakat biasa suku Bugis lainnya di Sulawesi Selatan menyatakan bahwa; dunia atas adalah tempat bersemayamnya 
Sange-Serri atau Dewi Padi, dengan pemahaman ini masyarakat suku Bugis menganggap bahwa loteng atau tollangeng dijadikan sebagai tempat penyimpanan padi atau hasil pertanian lainnya. Adanya struktur ruang yang jelas serta pola ruang yang unik pada ruang rakkeang rumah tradisional bangsawan suku Bugis menjadikan karakteristik yang khas dan melekat serta mampu menaungi penghuni dan melindungi diri dari gangguan alam yang teraga dan tidak teraga pada lingkungan sekitar menjadikan rumah tradisional Bangsawan Bugis di Bone Sulawesi Selatan menarik untuk diteliti secara mendalam.

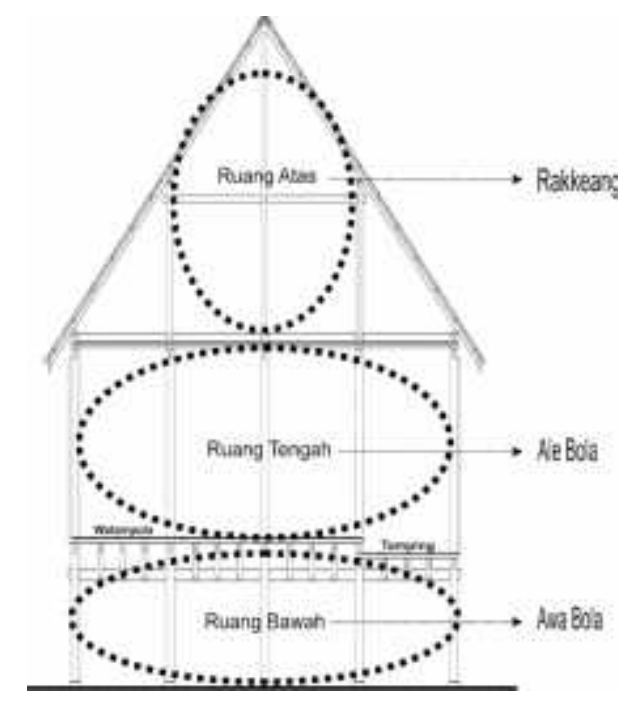

Gambar.1: Konsep susunan ruang secara vertikal rumah tradisional Bugis

(Sumber: Analisis Penulis 2016)

Metode yang digunakan adalah metode kualitatif dengan paradigma penelitian rasionalistik, yang bertolak dari kerangka teoritik dan dibangun dari pemaknaan hasil penelitian terlebih dahulu, sehingga sumber kebenaran yang menjadi acuan. Lokasi penelitian dilakukan didaerah utama suku Bugis di Sulawesi Selatan pada yaitu Kabupaten Bone. Pemilihan lokasi penelitian didasarkan pada pertimbangan basis kerajaan suku Bugis yang pernah berpusat di Bone $^{(12)}$. Sebagai obyek penelitian adalah ruang Rakkeang rumah tradisional Bangsawan suku Bugis di Bone yang kondisinya masih baik dan dihuni. Rumah yang dipilih sebagai kasus penelitian adalah rumah tradisional yang dipandang sebagai rumah asli bangsawan Bugis dengan kriteria struktur dan bentuk bangunan yang tidak mengalami perubahan signifikan yang dipilih secara acak dan mewakili bentuk komposisi dan elemen-elemen fasad yang sama.
Sumber Informasi ini ada dua, yaitu: 1) Informasi verbal, yaitu informasi yang berupa kata-kata atau penjelasan yang diperoleh saat melakukan wawancara mendalam yang dilakukan terhadap penghuni rumah tradisional bangsawan Bugis dan tokoh masyarakat yang berada pada lokasi obyek penelitian. 2) Informasi tekstual tertulis diperoleh dari media cetak berupa literatur atau tulisan yang terkait dengan fokus dan tema penelitian. Alat penelitian ini merupakan instrumen utama penelitian ini, adalah peneliti sendiri dengan latar belakang yang dimiliki digunakan untuk mengumpulkan informasi-informasi tekstual dan verbal serta menginterpretasikan makna simbolik yang ada pada obyek penelitian.

Kesulitan Dalam Penelitian yaitu penghuni rumah pada umumnya orang-orang modern pewaris kepemilikan rumah orang tuanya yang membuat dan menghuni rumah itu sebelumnya serta kurang mengetahui latar belakang didirikannya rumah tersebut,

\section{ISI PENELITIAN}

\subsection{Teori Bentuk pada Rumah Tradisional}

Bentuk rumah tradisional Bugis dapat diidentifikasikan melalui susunan timpa lajanya yang merupakan penutup ruang Rakkeang, yang dapat diklasifikasikan atas susunan (lanta) 5 untuk rumah raja, lanta 3 untuk keturunan bangsawan dan lanta 1 untuk masyarakat umum. Bentuk atap juga dihubungkan dengan arti simbol mikromakrokosmos, unsur alam sekitar serta dihubungkan dengan perbedaan status sosial penghuninya. Dari klasifikasi bentuk atap tersebut terdapat hierarki kesempurnaan/keutamaan dilihat dari kompleksitas struktur, teknik pengerjaan, jumlah material, biaya serta tenaga yang dibutuhkan. Perbedaan ini menunjukan perbedaan status sosial, sedangkan persamaan dalam susunan ruang menandakan adanya pandangan hidup yang diwujudkan melalui aturan-aturan dalam kehidupan rumah tangga.

Bahan utama umumnya kayu, yang dinilai sebagai bahan yang alami dan mengandung nilai-nilai baik . Ragam hias umumnya bersifat konstruktif (menyatu dengan elemen lain) dengan motif flora, fauna, alam, agama dan lain-lain. Dua aspek non-fisik dominan adalah arah dan lambang tubuh manusia. Hal itu juga akan mempengaruhi proses pembangunan rumah, dimana penentuan orientasi, waktu dan tempat merupakan hal yang penting, sedangkan lambang tubuh manusia menentukan skala dan bentuk rumah. Melalui bentuk, ruang berhubungan dengan tempat, kemudian dikenali, dikaitkan, diberi makna dan diidentifikasi sesuai kesepakatan budaya, yang menjelaskan bentuk spesifik, seperti sakralprofan, privat-publik, terbuka-tertutup dan lain-lain. 


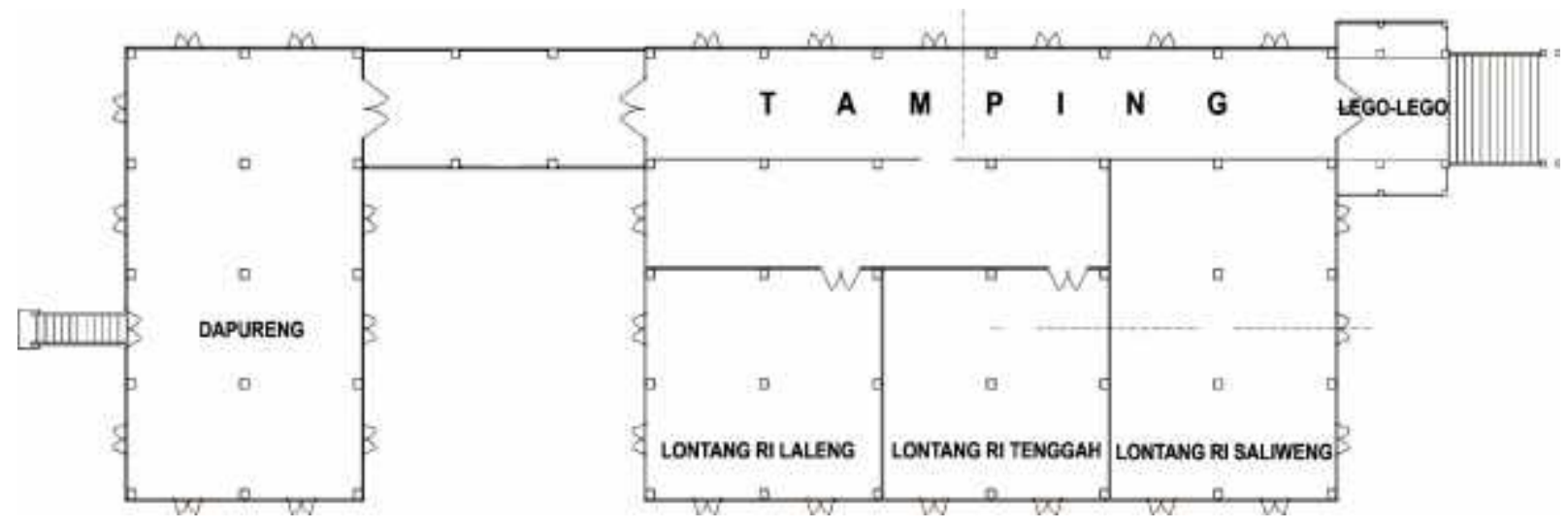

Gambar.2 : Konfigurasi massa ruang rumah tradisional bangsawan Bugis

(Sumber: Analisis Penulis 2016)

\subsection{Rumah Tradisional Bugis di Sulawesi Selatan}

Dalam naskah Sure Galigo dikemukakan tentang ihwal kejadian dunia bagi suku Bugis yang dikisahkan sebagai mitos To Manurung, yaitu turunnya manusia pertama dibumi disertai istananya yang bernama Soukotta, yang merupakan cermin pandangan masyarakat suku Bugis terhadap rumah bukan hanya sebagai faktor luar yang sekedar digunakan sebagai sarana perlindungan terhadap alam, akan tetapi merupakan suatu kesatuan nilainilai kehidupan dan spiritual, yang mengisyaratkan keselamatan hidup dunia dan akhirat, murah reseki dan terhindar dari bencana ${ }^{(6)}$. Soukotta bukanlah semata-mata istana atau kediaman Batara Guru sebagai manusia pertama dalam legenda Bugis tetapi sebagai penggambaran jagad raya yang merupakan mikrokosmos dan merupakan dasar arsitektural rumah tradisional Bugis. Demikian pula rumah tinggalnya sebagai wujud mikrokosmos, secara analogi terbagi atas tiga susunan secara vertikal yaitu : 1) Ruang Atas ( Rakkeang ) : Ruang ini dipandang sebagai ruang yang suci, dengan fungsi menyiratkan hal-hal yang sangat yang diagungkan. 2) Ruang Tengah ( Ale Bola ) : Merupakan ruang aktifitas penghuni sehari-hari (bersosialisasi), biasanya disebut sebagai badan rumah. 3) Ruang Bawah ( Awa Bola ) : Tempat ternak, tempat penyimpanan alat pekerjaan sehari-hari dan tempat santai.

Disamping itu tata ruang bangunan induk rumah tradisional Bugis secara horisontal terdapat Lontang/petak yaitu jarak antara tiang pada ruang dalam rumah Bugis. Bentuk dan fungsi lontang pada rumah golongan bangsawan dan rakyat biasa adalah sama, yang membedakan adalah luasannya, untuk rumah raja 9 petak, keturunan raja 4 sampai 7 petak, sedangkan masyarakat golongan biasa tidak bisa melebihi 3 petak. Susunan ruang dalam Alle Bola terbagi atas tiga zoning yang terdiri atas: 1) Ruang Depan (Lontang Risaliweng): memiliki fungsi seperti menerima tamu, tempat tidur tamu, tempat mengadakan pertemuan, tempat membaringkan mayat. 2) Ruang Tengah (Lontang Ritengngah): berfungsi sebagai tempat tidur bagi kepala keluarga bersama isteri dan anak-anaknya. Kegiatan keluarga juga berlangsung di ruang ini seperti makan, ruang bagi ibu yang akan melahirkan. 3) Ruang Belakang (Lontang Rilaleng): ruang ini berfungsi sebagai ruang anak gadis dan orang-orang tua yang lanjut usia

\subsection{Konsep Ruang Terhadap Fungsi, Bentuk dan Ekspresi Rumah Tradisional}

Keterkaitan Konsep Ruang Terhadap Fungsi, Bentuk dan Ekspresi rumah tradisional dapat diidentifikasikan pada produk tiga dimensi yaitu; produk budaya (budaya membangun), nilai personal dan interpersonal desain. Fungsi, bentuk dan ekspresi pada ruang terwujud sebagai fenomena fisik yang memberikan peluang untuk menjadi beragam, sebagai akibat respon masyarakat dengan latar lingkungan fisik, sosial, kultural dan ekonomi yang beragam pula. Untuk dapat memahami ruang hunian sebagai fenomena fisik menjadi jelas jika karakter kultur, pandangan dan tata nilai masyarakat setempat dapat digali dan ditemukan. Persamaan dan perbedaan kultur dengan kultur lainnya dapat dinilai dan ditandai berdasarkan unsur dalam sistem kebudayaan yang terangkum dalam 3 wujud, yaitu : 1) Culturals system, yaitu wujud kebudayaan sebagai kompleks ide-ide, gagasan, nilai-nilai, norma dan peraturan yang bersifat abstrak. 2) Social system, yaitu wujud kebudayaan sebagai kompleks aktifitas kelakuan yang berpola dari manusia dalam masyarakat. 3) Physical system, yaitu wujud kebudayaan benda-benda hasil karya manusia yang mempunyai sifat yang paling kongkrit, dapat diraba, diobservasi dan didokumentasikan atau disebut juga kebudayaan fisik. Ketiga wujud ini satu kesatuan sosial yang selalu ada pada setiap lingkungan budaya, dimana arsitektur merupakan bagian dari unsur kebudayaan tersebut ${ }^{(9)}$. Sistem-sistem tersebut saling berpengaruh dan membentuk keseimbangan, 
dengan demikian jika salah satu sistem mengalami perubahan akan berpengaruh terhadap sistim yang lain. Kesatuan sistem tersebut akan membentuk karakteristik/ciri khas yang dapat dikenali ${ }^{(10)}$.

Lebih mendalam oleh Habraken menilai gambaran konsep bentuk secara keseluruhan bangunan atau ruang arsitektur merupakan suatu kesatuan sistem yang terdiri atas: 1) Spatial system atau organisasi ruang terkait dengan konfigurasi pola ruang, letak ruang serta orientasi dan hirarki ruang. 2) Phisical system yang berhubungan dengan konstruksi dan bahan atau material yang digunakan oleh ruang, terdiri dari struktur rangka, konstruksi atap, lantai, dinding dan sebagainya. 3) Stylistic system yaitu kesatuan ekspresi bentuk komposisi elemen-elemen ruang serta komponen lay out dan ragam hias, baik yang ada pada ruang dalam maupun berada pada ruang luar.

\subsection{Sistem Spasial Ruang Rakkeang:}

a) Umumnya ruang Rakkeang terletak simetris dengan ruang bangunan induk rumah (Indo Bola), Letak ruang Rakkeang yang simetris ini cenderung mengikuti pola ruang pada bangunan tradisional Bugis yang terdiri atas lontang ri saliweng, lontang ri tenggah dan lontang ri laleng. Tata ruang ini merupakan simbol privasi dari ruang rakkeang bangsawan Bugis agar senantiasa terjaga oleh semua anggota keluaraga yang ada didalam bangunan induk rumah dan tidak boleh dimasuki oleh orang lain kecuali anggota keluaraga.

b) Letak ruang Rakkeang yang simetris dengan Indo Bola memiliki ukuran lebih luas dan lebih lebar dibandingkan yang Asimetris. Hal ini merupakan perwujudan simbol derajat kebangsawanan pemilik ruang Rakkeang tersebut, dimana dalam penelitian ini ditemukan semakin besar ukuran ruang Rakkeang, semakin tinggi derajat kebangsawanan pemilik rumah tersebut. hal ini merupakan salah satu perwujudan sebagai golongan bangsawan yang ingin menunjukkan derajat kebangsawanannya di wilayah yang dikuasainya ${ }^{(13)}$.

c) Orientasi ruang Rakkeang simetris rumah tradisional bangsawan Bugis di Bone umumnya mengikuti orientasi Indo Bola menghadap kearah jalan, sedangkan ruang Rakkeang asimetris menghadap kearah ruang terbuka yang terdapat disebelah kiri kanan badan rumah (Indo Bola), hal ini ditandai dengan lubang jalan masuk ruang Rakkeang tersebut, dimana letak lubang jalan masuk ruang Rakkeang yang ditemui dilapangan umumnya berada sejajar diatas ruang tidur anak gadis Bangsawan atau berada pada lontang ri laleng bangunan induk rumah. Orientasi Rakkeang semata-mata dipengaruhi letak lubang jalan masuk atau pencapaian ruang Rakkeang dan tidak terfokus pada satu arah mata angin (utara, selatan, timur, barat) karena menganggap semua arah baik secara ritual. Pencapaian sebagai arah orientasi sangat dipengaruhi oleh kebutuhan privasi fungsional dan pemikiran rasional sang pemilik rumah yang mendasarkan pada mental spiritual kepercayaan yang dianut agar ruang privasi tetap terjaga selamanya. Sedangkan arah hadap ruang ke ruang terbuka didasari oleh adanya anggapan terhadap kondisi iklim tropis, yaitu untuk mendapatkan pengaliran udara dan pencahayaan yang baik kedalam ruang Rakkeang. Konsep ini sesuai dengan falsafah Sulapa Eppana Ogie' yang menganggap alam raya ini terdiri dari empat segi penjuru mata angin, oleh karenanya ruang Rakkeang umumnya simetris mengikuti arah bangunan induk rumah Bugis sebagai mikrokosmos berbentuk segi empat. Bangunan rumah boleh menghadap ke segala arah manapun, karena semua arah sama nilai-nilai ritualnya.

d) Hirarki ruang Rakkeang yang ditandai oleh pembatas yang tegas berupa lantai Rakkeang dan tangga penghubung ruang Rakkeang dengan ruang Indo Bola sebagai simbol yang disucikan dan tinggikan atau hal yang diagungkan. Dimana ruang Rakkeang letaknya lebih tinggi dari pada ruang-ruang lainnya yang ada dalam rumah Bangsawan Bugis Bone. Hirarki seperti ini terdapat pada konsep duality dalam bangunan rumah tradisional bangsawan Bugis, yang membedakan antara dua hal yang berlawanan seperti; tinggi dan rendah serta bersih dan kotor. Pemisahan ruang Rakkeang yang tegas juga merupakan simbol penghargaan pemenuhan kebutuhan privasi penghuninya akan ketenangan ritual berkomunikasi dengan Dewata Seuwae. Hal ini dikarenakan para bangsawan menganggap ruang Rakkeang adalah tempat bersemayamnya Dewata Seuwae. Selain itu, tangga pada jalan masuk ke ruang Rakkeang terletak diruang tidur anak gadis Bangsawan Bugis di Bone dikarenakan fungsi ruang Rakkeang juga digunakan sebagai tempat berias, menenun dan bermain anak gadis Bangsawan, hal ini dikarenakan anak gadis bangsawan tidak diperbolehkan bermain diluar rumah seperti gadis kampung lainnya, demikian juga untuk aktifitas menenun anak gadis Bangsawan tidak diperbolehkan menenun dibawah rumah/awa bola seperti yang sering dilakukan anak gadis kampung lainnya. Hal ini merupakan simbol kewibawaan anak gadis bangsawan Bugis Tersebut.

\subsection{Sistem Fisik Ruang Rakkeang:}

a) Modul struktur alliri (tiang rakkeang) kearah panjang dan lebar tidak sama, hal ini disebabkan oleh pola ruang Rakkeang simetris dan asimetris membentuk memanjang kebelakang. Jumlah alliri pada ruang bentuk simetris lebih banyak dibandingkan Rakkeang asimetris dikarenakan pola ruang simetris yang lebih besar dan luas 
dibanding asimetris, sedangkan untuk ukuran tiang alliri yang lebih besar sebagai simbol derajat sosial pemilik rumah dan juga dikarenakan ketinggian dan bentangan struktur atap yang ditopang sangat panjang, hal ini dimugkinkan karena pola ruang Rakkeang umumnya simetris dengan badan rumah atau Indo Bola.

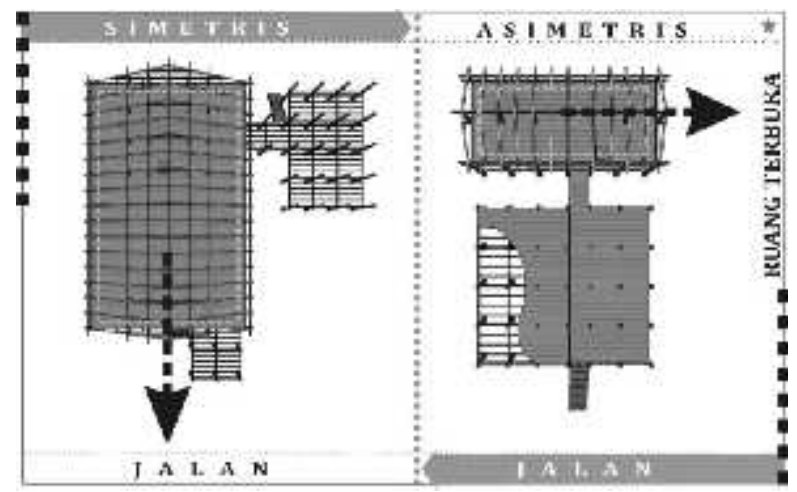

Gambar.3: Sistem Spasial Ruang Rakkeang

(Sumber: Analisis Penulis, 2016)

b) Sistem konstruksi kayu pada struktur lantai papan ruang Rakkeang menggunakan konsep Mappasituppu (menumpuk) pada struktur tinebba dan pattolok riase. Masing-masing ruang Rakkeang pola simetris dan asmetris lebih cenderung mengikuti pola, ukuran dan luas lantai ruang yang sejajar secara vertikal ruang dibawahnya.

c) Pada dinding atau renring ruang Rakkeang rumah tradisional Bangsawan Bugis di Bone tidak memakai renring secara langsung pada arah kiri dan kanan ruang Rakkeang, hal ini dikarenakan posisi ruang rakkeang berada paling atas yang juga berfungsi sebagai penutup/atap rumah dengan konstruksi kayu, dimana konsep rumah tradisional Suku Bugis bentuk atapnya pelana (atap kampung) dengan kemiringan $45^{\circ}$ derajat,

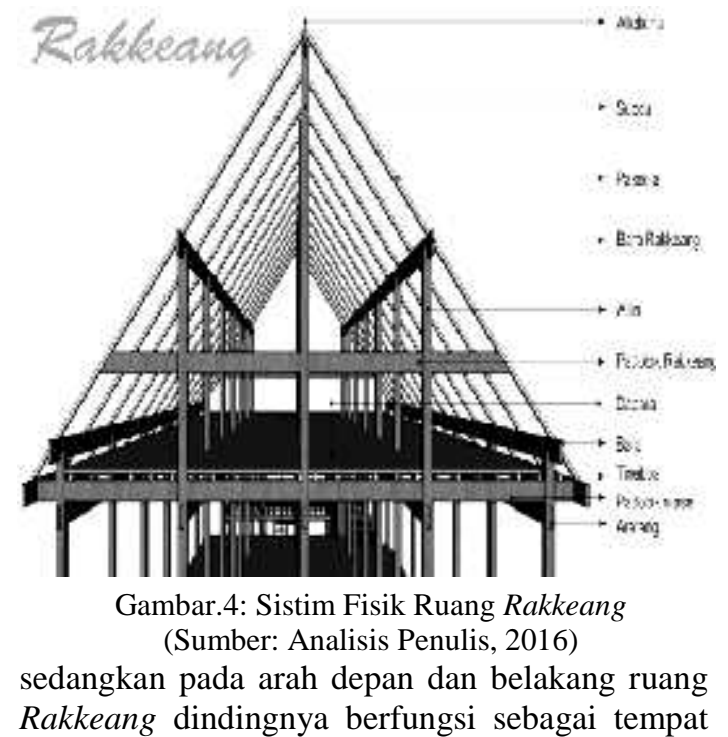

dudukan timpa laja yang merupakan status simbol derajat kebangsawanan pemilik rumah dan juga berfungsi sebagai ventilasi/lubang angin pada ruang Rakkeang), serta bahan material penutup atapnya (dinding arah kiri kanan Rakkeang) banyak dipengaruhi oleh kemampuan penghuni secara ekonomis dan tingkatan derajat sosial yang lebih tinggi.

\subsection{Bentuk Elemen-Elemen Ruang Rakkeang:}

a) Penggunaan tiang-tiang (alliri) Rakkeang yang besar, tinggi dan kokoh, hal ini bukan saja terkait masalah konstruksi alliri yang menerus dari ruaang bawah (awa bola) keruang atas (Rakkeang) atau susunan struktur atap yang ditopang diatasnya serta pola keseimbangan komposisi pada badan dengan kepala bangunan rumah, akan tetapi juga lebih dipengaruhi oleh simbol kekuasaan dan kewibawaan bangsawan orang Bugis yang menempati rumah tersebut tentang aturan atau adat istiadat yang masih dipegang dalam rangka membangun rumah tradisional Bugis. Hal ini diyakini bahwa semakin besar allri yang sampai keruang Rakkeang semakin tinggi status derajat sosialnya dilingkungan masyrakatnya, hal ini dikarenakan untuk mendapatkan tiang-tiang kayu yang besar, panjang serta kuat dan utuh sampai keatas diruang Rakkeang sangatlah susah dibutuhkan satu batang pohon besar untuk satu tiang/alliri rumah. Hal tersebut diatas hanya bisa didapatkan atau dimiliki oleh seorang raja atau keturunan Raja, Sejalan dengan kategorisasi pemikiran Ronald (1993) elemen-elemen fisik pada rumah tradisional bangsawan merupakan manifestasi kekuasaan dan kekuatan sebagai cerminan karakter tubuh manusia yang dimilikinya yaitu dirinya sendiri.

b) Lubang jalan masuk ruang Rakkeang salah satu simbol yang sangat privasi dikarenakan ukuran lubang yang kecil dimaknakan orang yang bisa memasukinya dikhususkan bagi anggota keluarga yang mempunyai garis keturunan darah langsung yang tinggal dirumah tersebut. Demikian juga letak lubang Rakkeang yang sejajar ke atas ruang tidur anak gadis merupakan simbol privasi, dimana pada konsep ruang rumah tradisional suku Bugis ruang tidur anak gadis ditempatkan pada ruang atau lontang yang paling dalam (Lontang rilaleng), yang bermakna ruang tersebut sangat diproteksi dari ganguan luar.

c) Ventilasi pada ruang Rakkeang semata-mata bertujuan untuk mendapatkan pencahayaan atau penerangan alami dan penghawaan cukup tanpa makna khusus pada bentuk ventilasinya. Pencahayaan dan penghawaan alami yang terdapat pada ruang Rakkeang umumnya didapatkan dari susunan timpa laja sebagai penutup muka belakang ruang Rakkeang Rumah bangsawan tersebut. Hal ini menandakan bahwasanya kurangnya bukaan yang 
berhubungan dengan dunia luar, menegaskan ruang Rakkeang merupakan ruang yang sangat diproteksi dari ganguan dunia luar.

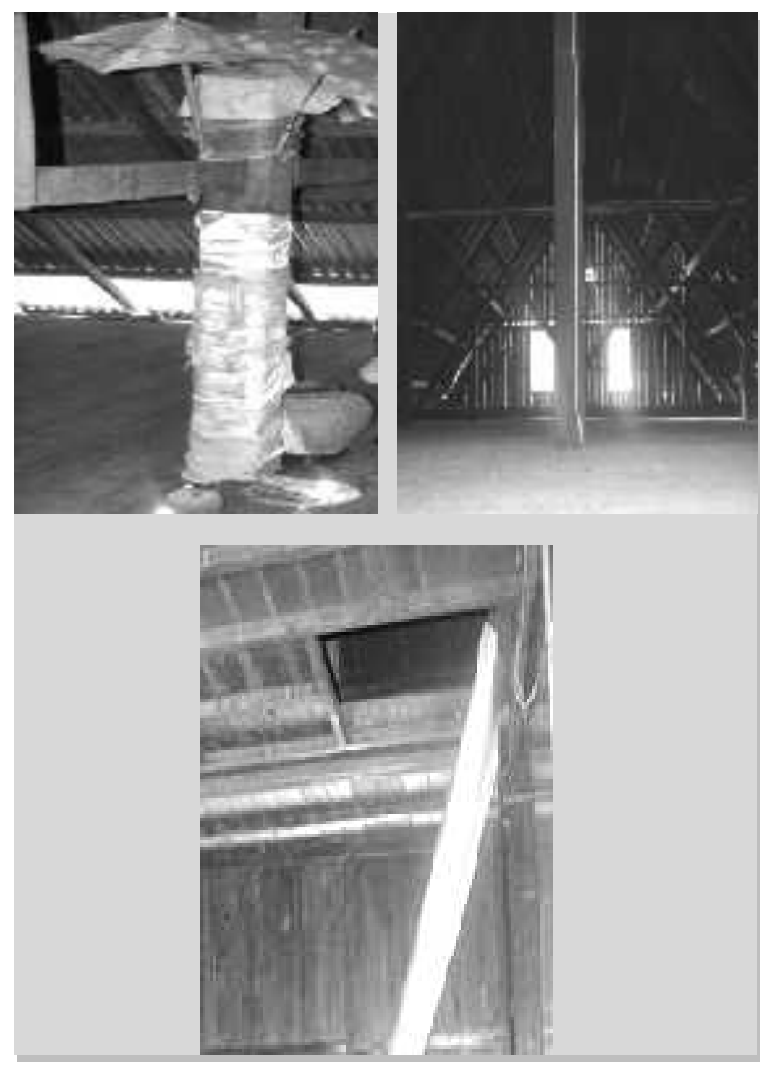

Gambar.5: Tiang, Ventilasi dan Lubang Masuk Rakkeang

(Sumber: Koleksi Penulis 2016)

d) Tangga Rakkeang terbuat dari kayu yang berfungsi sebagai jalan masuk dan juga merupakan salah satu simbol privasi ruang rakkeang, hal ini bisa dilihat dari perletakan tangga pada semua kasus penelitian yang di jumpai umumnya tangga ruang Rakkeang terletak di kamar tidur anak gadis yang tidak bisa dimasuki atau dilihat oleh siapapun yang tidak memiliki garis keturunan darah secara langsung kecuali Ayah, ibu, nenek dan kakek dan saudara kandung sang gadis bangsawan tersebut.

e) Penggunaan timpa laja bukan saja sebagai struktur penutup atap bagian muka dan belakang atau sebagai ventilasi lubang angin pada Rakkeang, akan tetapi lebih dominan sebagai aturan-aturan adat yang masih berlaku pada rumah trumah radisional Bangsawan Bugis yang merupakan simbol strata sosial pemiliknya.

f) Lay out prabot pada ruang Rakkeang Bangsawan Bugis yang ditemui umumnya menyesuaikan fungsi dari pada ruang Rakkeang sebagai tempat berkomunikasinya raja secara ritual dengan Dewata Seuwae. Selain itu Lay out Perabot yang ditemui diperuntukkan tempat penyimpanan pusaka keluarga dan juga alat berias dan aktifitas lainnya untuk anak gadis bangsawan. Penandaan kesemua lay out yang ada merupakan symbol kesakralan dan privasi ruang Rakkeang tersebut

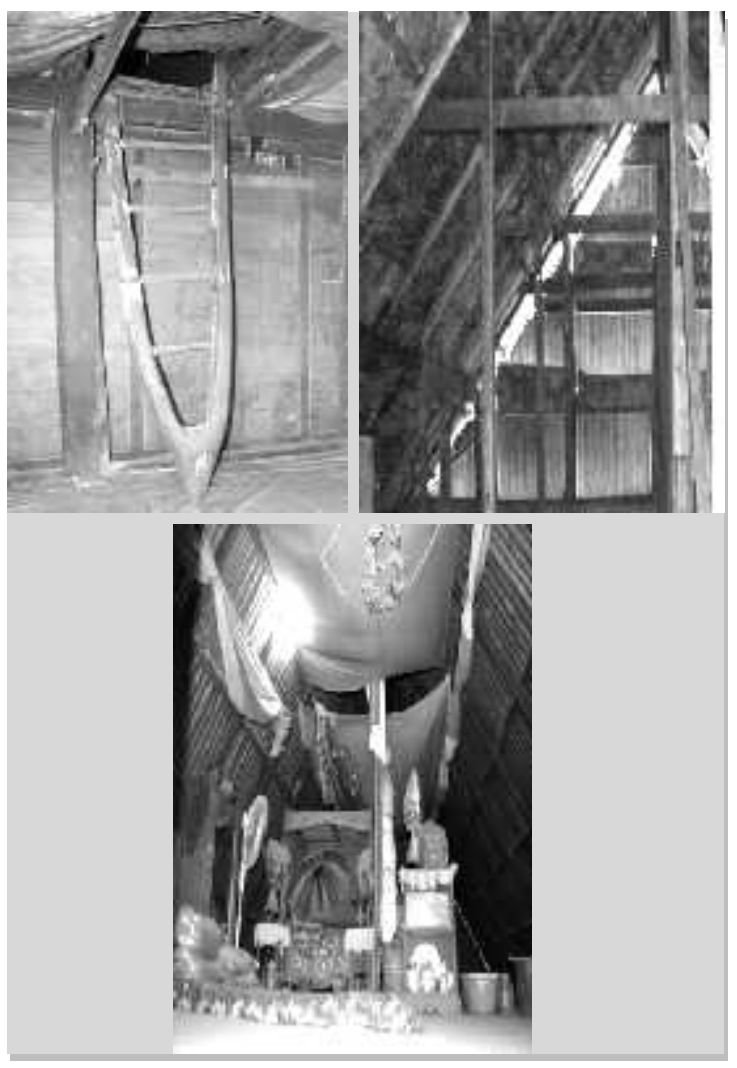

Gambar.6: Tangga, Timpa Laja, Lay Out Rakkeang

(Sumber: Koleksi Penulis, 2016)

\section{KESIMPULAN \& SARAN}

Kesimpulan berdasarkan hasil penelitian dan pembahasan konsep bentuk ruang Rakkeang rumah tradisional Bangsawan Bugis di Bone Sulawesi Selatan, disimpulkan bahwa :

\subsection{Konsep bentuk ruang Rakkeang secara spasial}

terletak simetris dengan ruang induk rumah (Indo Bola) dan cenderung mengikuti pola ruang yang ada dibawahnya yang terdiri atas lontang ri saliweng, lontang ri tenggah dan lontang ri laleng. Ruang Rakkeang yang simetris memiliki ukuran lebih luas dan lebih lebar dibandingkan yang Asimetris. Hal ini perwujudan simbol derajat kebangsawanan pemilik ruang Rakkeang tersebut, dimana dalam penelitian ini ditemukan semakin besar ukuran ruang Rakkeang, semakin tinggi derajat kebangsawanan pemilik rumah tersebut. Sedangkan konsep orientasi ruang Rakkeang mengikuti orientasi Indo Bola menghadap kearah jalan, hal ini ditandai dengan lubang dan tangga jalan masuk ruang Rakkeang terletak sejajar diatas ruang tidur anak gadis Bangsawan atau berada pada lontang ri laleng indo bola. Pada hirarki ruang Rakkeang ditandai oleh pembatas yang tegas berupa lantai dan tangga 
penghubung ruang Rakkeang dengan ruang Indo Bola sebagai makna diagungkan karna berada pada ruang yang tertinggi pada rumah, hal ini merupakan simbol kewibawaan dengan fungsi yang khusus dan sebagai hal yang sifatnya privasi serta menyatakan hirarki yang melekat para pemakai ruang Rakkeang tersebut.

\subsection{Konsep ruang Secara fisik}

Terlihat pada sistim fisik pada ruang Rakkeang yang lebih besar yaitu terdapat pada Rakkeang bentuk simetris, serta mempunyai kemampuan variasi dan sistem konstruksi yang lebih leluasa. Seperti halnya penggabungan struktur bentuk atap pelana (kampung) dan atap limasan. Apabila ditinjau lebih dalam, mengapa konstruksi fisik Rakkeang asimetris lebih kecil dan terkesan sempit, hal ini cenderung sebagai simbol status derajat sosial dan keterbatasan kemampuan penghuni yang secara sosial dan ekonomis mempunyai tingkatan yang lebih rendah dari pada golongan penghuni ruang Rakkeang simetris. Sehingga dengan keterbatasn tersebut mereka mempergunakan struktur konstruksi yang terjangkau serta relatif lebih mudah didapatkan dan dapat dikerjakan lebih cepat.

\subsection{Konsep bentuk elemen-elemen ruang Rakkeang}

Dimaksudkan agar hegemoni kebangsawanan tetap diterjaga, karena setiap elemen-elemen ruang Rakkeang yang ada dapat mempengaruhi persepsi bagi yang melihat sebesar apa pengaruh seseorang dan setinggi apa status sosialnya dalam masyarakat. Hal-hal yang dapat disarankan penulis kepada pihak berkepentingan demi memperluas manfaat penelitian ini adalah terbatasnya jumlah obyek yang diteliti dan pembatasan wilayah penelitian dapat mengurangi keakuratan temuan penelitian. Oleh karena itu untuk membuktikan hypothesis tersebut kepada peneliti berikutnya perlu melakukan komparatif yang lebih luas dengan obyek yang lebih banyak dalam kurun waktu yang berbeda, sehingga semakin memperkaya wacana tentang arsitektur rumah tradisional Bugis dinusantara tercinta ini, yang saat ini masih sangat jarang dilakukan. Penulis menyadari, karena keterbatasan waktu dan kesimpulan yang bersifat hypothesis tersebut masih perlu dikaji lebih mendalam, oleh karena itu perlu dilakukan penelitian lebih lanjut dan mendalam. Temuan penelitian ini tidak hanya sekedar untuk mengetahui seperti apa dan bagaimana karakteristik ruang Rakkeang rumah tradisional bangsawan Bugis di Bone Sulawesi Selatan, namun lebih dari itu proses terbentuknya arsitektur rumah tradisional Bugis hendaknya juga dapat digali dan diteliti lebih mendalam guna berbagi pengalaman kepada arsitekarsitek selanjutnya bagaimana merencanakan suatu karya arsitektur yang peduli terhadap lingkungan sekitarnya dan mengangkat nilai-nilai kearifan lokal daerahnya serta bagaimana melakukan penyesuaianpenyesuaian sehingga nilai-nilai arsitektur tradisional setempat tidak akan kehilangan identitas jati dirinya. Akhirnya penulis menyarankan bahwa “ dengan mempelajari arsitektur rumah tradisional Bugis, para arsitek dapat menentukan sikap terhadap perencanaan dan perancangan pembangunan pada masa-masa yang akan datang.

\section{DAFTAR PUSTAKA}

- Akbar, Andi Muhammad, "Faktor-Faktor Pembentuk Karakter Arsitektur Rumah Tradisional Bangsawan Bugis di Sulawesi Selatan". Tesis untuk memperoleh gelar Magister Teknik Arsitektur Universitas Gadjah Mada, Yogyakarta: UGM, 2007.

- Mattulada, Kebudayaan Bugis-Makassar, dalam Koentjaraningrat. Manusia dan Kebudayaan di Indonesia. Jakarta: Djambatan, 1997.

- Tjahjono, G. Cosmos, Center and Duality in Javanese Architectural Tradition; The Symbolic Dimension of House Shapes in Kotagede and surroundings. Dissertation Doctor of Phylosophy, University of California at Berkeley. 1990.

- Silas, J. Arsitektur Tradisional Daerah Jawa Timur. Proyek Inventarisasi dan Dokumentasi Kebudayaan Daerah, Depdikbud. Surabaya. 1984.

- Pangarsa, G.W, Tjahjono, R dan Pamungkas,S.T. Deformasi dan Dampak Ruang Arsitektur Madura Pedalungan di Lereng Utara Tengger. Laporan Hasil Penelitian, Universitas Brawijaya. Malang. 1994.

- Mappangara, Suriadi, Ensiklopedia Sejarah Sulawesi Selatan sampai Tahun 1905. Makassar: Dinas Kebudayaan dan Pariwisata Provinsi Sulawesi Selatan, 2004.

- Muhammad, Amin Data, Bentuk Rumah BugisMakassar, Ujung Pandang: Depdikbud, 1990.

- Hamid, Abu, Kebudayaan Bugis. Makassar: Dinas Kebudayaan dan Pariwisata Provinsi Sulawesi Selatan, 2006.

- Koentjaraningrat, Kebudayaan, Mentalitet dan Pembangunan. Jakarta: Gramedia Pustaka Utama, 2004.

- Lewcock, Ronald dan Gerald Brans, The Boats as an Architectural Symbol, dalam Paul Oliver (ed) Shelter, Sign, and Symbol. New York: The Overlock Press, 1980.

- Habraken, N.J, General Principles Of About The Way Environment Of Architecture, Massachussets: MIT, 1978.

- Pelras, Christian, Manusia Bugis. Jakarta: Forum Jakarta-Paris Ecole Francaise d"Extreme-Orient, 2006.

- Ronald, Arya, 1993. Ciri-ciri Karya Budaya di Balik Tabir Keagungan Rumah Jawa, Yogyakarta: Uneversitas Atmajaya, 1993.

- Kluckhohn, C, dalam Koentjaraningrat, Kebudayaan, Mentalitet dan Pembangunan, Jakarta: Gramedia Pustaka Utama, 2004. 